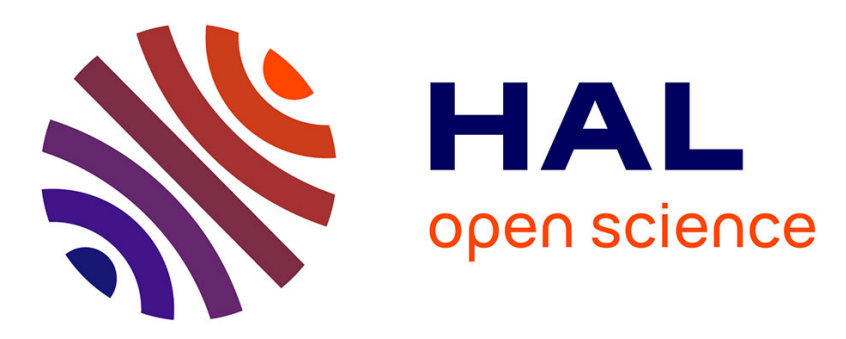

\title{
Genetic diversity of agricultural crops in Flanders over the last five decades
}

\author{
Marijke Meul, Frank Nevens, Dirk Reheul
}

\section{To cite this version:}

Marijke Meul, Frank Nevens, Dirk Reheul. Genetic diversity of agricultural crops in Flanders over the last five decades. Agronomy for Sustainable Development, 2005, 25 (4), pp.491-495. hal-00886301

\section{HAL Id: hal-00886301 \\ https://hal.science/hal-00886301}

Submitted on 1 Jan 2005

HAL is a multi-disciplinary open access archive for the deposit and dissemination of scientific research documents, whether they are published or not. The documents may come from teaching and research institutions in France or abroad, or from public or private research centers.
L'archive ouverte pluridisciplinaire HAL, est destinée au dépôt et à la diffusion de documents scientifiques de niveau recherche, publiés ou non, émanant des établissements d'enseignement et de recherche français ou étrangers, des laboratoires publics ou privés. 


\title{
Genetic diversity of agricultural crops in Flanders over the last five decades
}

\author{
Marijke MEUL ${ }^{a *}$, Frank NEVENS ${ }^{\mathrm{a}}$, Dirk REHEUL ${ }^{\mathrm{b}}$ \\ ${ }^{a}$ Flemish Policy Research Centre for Sustainable Agriculture, Potaardestraat 20, 9090 Gontrode, Belgium \\ ${ }^{\mathrm{b}}$ Department of Plant Production, Ghent University, Coupure Links 653, 9000 Gent, Belgium
}

(Accepted 10 June 2005)

\begin{abstract}
In this study, we describe the evolution of crop diversity in Flanders, using three indicators to measure diversity between crops and within crops: the Shannon index $(\mathrm{H})$, the evenness index $(\mathrm{E})$ - both used for diversity between and within crops - and genetic relatedness between varieties (CP). Despite the significant increase in the number of crops in Flanders, from 67 in 1950 to 101 in 2002 , the results show a weak decrease in crop diversity between 1950 and 2002: $\mathrm{H}$ decreased from 2.52 to 2.50 and E decreased from 0.58 to 0.53 . This apparent contradiction can be explained by the fact that the 'new' crops are mainly vegetables, which only have a small share in the total agricultural area, and thus hardly influence the overall crop diversity. The evolution of genetic diversity between varieties (within crops) from 1980 to 2002 is crop-specific. For maize, the number of cultivars with a high CP $(\geq 0.125)$ increased from 1.8 to $7.5 \%$, indicating a decrease in genetic diversity. For potato and winter wheat the number of cultivars with $\mathrm{CP} \geq 0.125$ decreased (from 7.3 to $3.7 \%$ and from 6.9 to $6.0 \%$, respectively), indicating an increase in genetic diversity within these crops, which is confirmed by the increase in the crops' $\mathrm{H}$ and $\mathrm{E}$ values.
\end{abstract}

crops / Flanders / genetic diversity / indicator / sustainable agriculture

\section{INTRODUCTION}

Diversity of agricultural crops enhances the stability and the sustainability of agro-ecosystems, since high crop diversity contributes to a higher diversity of associated wildlife species and habitats, therefore contributing to agro-biodiversity in general (OECD, 2001; Marshall et al., 2003). During the last few decades, the area planted with major crops has increased at the expense of the area of minor crops. For example, in Flanders maize suddenly became a major crop in the 1970s and its area has increased ever since, at the expense of some former important crops such as rye, barley, oat and fodder beet. Moreover, the rotation of crops has decreased, both in space and in time, causing a general decrease in crop diversity. However, the growing concern to reduce pesticide application highlights the importance of diversity between and within crops, since genetic diversity offers opportunities to reduce the spread of diseases and pests and to slow down resistance development (Finckh et al., 2000).

Genetic erosion has significantly increased from the beginning of the 20th century, caused by the introduction of modern plant breeding (Vellvé, 1993; Clunies-Ross and Mangolds, 1995) and the development of new, mechanized production methods. Modern plant breeding resulted in uniform varieties, going hand in hand with uniform production techniques.
The breeding of our current, highly-performing crop varieties started from genetically diverse landraces and wild varieties. Continuous selection and breeding caused a shift in crop phenotype and genotype. On the one hand, breeding has led to an increase in genetic diversity, through the search for particular characteristics relating to growth habit, seed production, etc. On the other hand, selection and breeding have caused genetic erosion, since only the most suitable plants and varieties, often in terms of production, were selected (Wascher, 2000; OECD, 2001).

Bertin et al. (2001) concluded that with as little as ten original varieties, the genetic base of modern spelt (Triticum spelta L.) in Europe has become very narrow. Also, for chicory (Cichorium intybus L.) and sugar beet (Beta vulgaris L.), a great loss of genetic diversity in modern varieties has been shown (Bellamy et al., 1996; Desplanque et al., 1999; Van Stallen et al., 2000). For some other crops, however, it seems there has been no or only little genetic erosion. Donini et al. (2000) did not find any substantial decrease in genetic diversity in winter wheat (Triticum aestivum L.) varieties in the UK since 1930. Other studies concerning genetic diversity of wheat and barley (Hordeum vulgare L.) confirmed these results (Reeves et al., 1999; Manifesto et al., 2001; Christiansen et al., 2002).

Witcombe (1999) concludes that in regions where modern crop varieties are well established, plant breeding does not

* Corresponding author: marijke.meul@ugent.be 
necessarily cause a loss of genetic diversity; in some cases even an increase is observed. However, in regions where mainly traditional varieties and landraces are grown, the introduction of modern varieties and modern plant breeding often causes a loss of genetic diversity.

Today, it is common knowledge that genetic diversity within crops is of major importance as a unique and irreplaceable source for future plant breeding (FAO, 1996; Tripp and van der Heide, 1996; Collins and Hawtin, 1999; Dotlacil et al., 2001) that should allow us to cope with new production methods, changing climatic conditions or changing consumer demands.

Hence it is important to monitor diversity between and within crops and to follow up the evolution in diversity. In this study, we develop indicators for agricultural crop diversity in Flanders (Belgium) and we give an overview of the evolution during the last few decades. We consider diversity at two levels: diversity between crops and genetic diversity within crops (between varieties). This study is part of a 6-year research project concerning the development of a set of indicators that will be used by the Flemish government to guide and evaluate agricultural policy in terms of sustainability.

\section{MATERIALS AND METHODS}

\subsection{Indicators}

Indicators are used to quantify complex phenomena that are difficult or even impossible to measure exactly. A good indicator meets a number of criteria (NERI, 1995; Delbaere, 2003): it is relevant, reliable, repeatable, applicable, practicable and normative (possibility of comparing with a baseline value).

The three indicators we used - the Shannon index $(H)$, the evenness index $(E)$ and relatedness between varieties $(\mathrm{CP})-$ all meet the criteria stated above. We used indicators $H$ and $E$ to estimate both diversity between crops and genetic diversity of varieties within crops; $\mathrm{CP}$ is an indicator for genetic diversity between varieties within crops.

\subsection{Diversity between crops}

To study all crops used in agricultural and horticultural production in Flanders, we relied on the data of the Belgian National Institute of Statistics (NIS, 1950-2002), which organizes a yearly survey on each farm in Belgium. All farmers are legally bound to respond to the questionnaire and thus to report which crops they grow on which area.

We assessed the evolution of the overall crop diversity in Flanders by calculating the Shannon and evenness diversity indices using the NIS data from the years 1950, 1960, 1971, 1980, 1990, 2000 and 2002.

Both indices simultaneously account for the number of crops and for their share in total agricultural area. The Shannon index (Shannon and Weaver, 1949), a diversity index often used in ecology, is calculated as:

$$
H=-\sum_{i=1}^{N} p_{i} \cdot \ln p_{i}
$$

where $p_{i}$ is the share of crop $i$ (=area of crop $i /$ total agricultural area) and $N$ is the total number of crops. Diversity $(H)$ increases when the number of crops increases, and/or when the crop area shares are more evenly distributed. The evenness index (Pielou, 1966) is calculated as:

$$
E=\frac{H}{H_{\text {max }}}=\frac{H}{\ln N},
$$

where $H_{\max }=\ln N$, the maximum Shannon index. $E$ varies between 0 and 1: $E=1$ when all crops have the same area; all crops are then equally important and diversity is high. The value of $E$ is close to 0 when a limited number of crops take up a major part of the agricultural area.

\subsection{Diversity within crops}

We assessed diversity within a crop by the above-mentioned Shannon and evenness indices, using the total specific crop area and the areas cropped with different varieties as data. In addition, we determined the relatedness between varieties, by calculating pairwise relationships, based on pedigree information. This pairwise relationship was quantified by the coefficient of parentage $(\mathrm{CP})$. The $\mathrm{CP}$ between two individuals is the probability that two random gametes, one from each individual, carry alleles that are identical by descent (Falconer, 1981). The CP between two varieties $\mathrm{P}$ and $\mathrm{Q}$ is calculated as:

$$
C P_{P Q}=\frac{1}{4}\left(C P_{A C}+C P_{A D}+C P_{B D}\right),
$$

where $\mathrm{P}$ 's parents are $(\mathrm{A} \times \mathrm{B})$ and $\mathrm{Q}$ 's parents are $(\mathrm{C} \times \mathrm{D})($ Falconer, 1981).

When $\mathrm{P}$ and $\mathrm{Q}$ have one common parent, while all other parents are mutually not related in any way, this will result in a $\mathrm{CP}=0.125$. Further, a $\mathrm{CP}=0.0625$ represents a cousin-cousin relationship between $\mathrm{P}$ and $\mathrm{Q}$. When $\mathrm{CP}=0.03125, \mathrm{P}$ and $\mathrm{Q}$ are second cousins and when $\mathrm{CP}=0, \mathrm{P}$ and $\mathrm{Q}$ are not related in any way.

When a specific crop has a high number of varieties with a high pairwise $\mathrm{CP}(\geq 0.125)$, relatedness between the varieties is high and we presume genetic diversity within this crop to be low.

We selected three crops to estimate within-crop diversity: maize, potato and winter wheat. Together, they represented $57 \%$ of total agricultural area (excl. meadows and pasture) in Flanders in 2002 . For each crop, we compared the situation in 2002 with the one in 1980.

\section{RESULTS AND DISCUSSION}

\subsection{Diversity between crops}

The number of crops in Flanders increased from 67 in 1950 to 101 in 2002. The values of the Shannon and evenness diversity indices increased between 1950 and 1971, subsequently decreased from 1971 to 1990 and became more or less stable from 1990 on (Fig. 1). Overall, between 1950 and 2002, $H$ decreased from 2.52 to 2.50 and $E$ decreased from 0.58 to 0.53 . So, despite the increasing number of crops, there is no general increase in the diversity indices between 1950 and 2002; we 
Table I. The share (\%) of arable crops and vegetables in the total agricultural area in Flanders (pastures and meadows excluded).

\begin{tabular}{lccccccc}
\hline & 1950 & 1960 & 1971 & 1980 & 1990 & 2000 & 2002 \\
\hline Arable crops & 92 & 91 & 90 & 92 & 90 & 88 & 91 \\
Vegetables (outdoor) & 1 & 1 & 3 & 3 & 4 & 4 \\
\hline
\end{tabular}

Shannon index $(\mathrm{H}) \quad$ Evenness index $(\mathrm{E})$

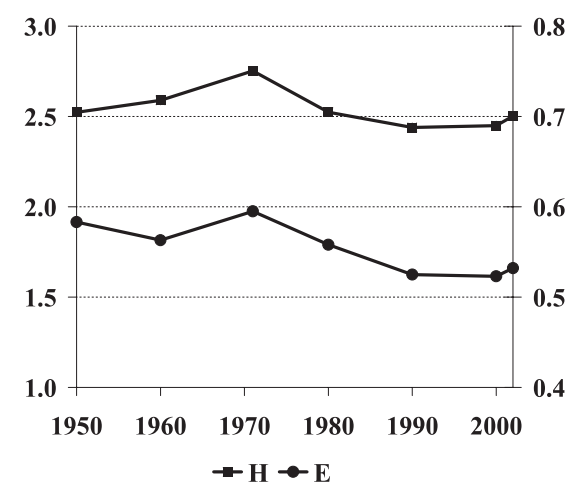

Figure 1. Shannon index and evenness index for crops in Flanders from 1950 to 2002 .

even notice a decrease. This is caused by the fact that the 'new' crops are mainly vegetables, which only have a small share in the agricultural area (Tab. I). The evolution in the dominant arable crops therefore has a larger impact on the overall crop diversity.

Figure 2 shows the evolution of the diversity indices for both arable crops and vegetables. For vegetables, we observe an increase in both diversity indices, indicating an increase in diversity. For arable crops there was an increase in the indices between 1950 and 1971, but a sharp decrease between 1971 and 1990. To a large extent, the decrease can be explained by the significant increase in the maize area, at the expense of a number of other crops.

\subsection{Genetic diversity within crops}

The values of the Shannon and evenness indices for potato and winter wheat increased between 1980 and 2002, indicating an increase in genetic diversity within the crops (Tab. II). For maize, there were no reliable data available to calculate the indices in 1980. In 2002, the value of the indices (in particular $H$ ) is higher for maize, compared with potato and winter wheat. This is caused by a very high number of available maize varieties (287 varieties), compared with potato or winter wheat varieties (both 43 varieties).

From 1980 to 2002, the number of maize cultivars with a high CP ( $\geq 0.125)$ increased, from 1.8 to $7.5 \%$. Recent maize varieties are often closely related, because seed companies cross top inbred lines with many other lines, thus creating a series of consanguineous varieties. For potato and winter wheat we observed a lower share of variety pairs with a high $\mathrm{CP}$ $(\geq 0.125)$ in 2002 , compared with 1980 . This indicates an increase in genetic diversity between varieties of these crops.
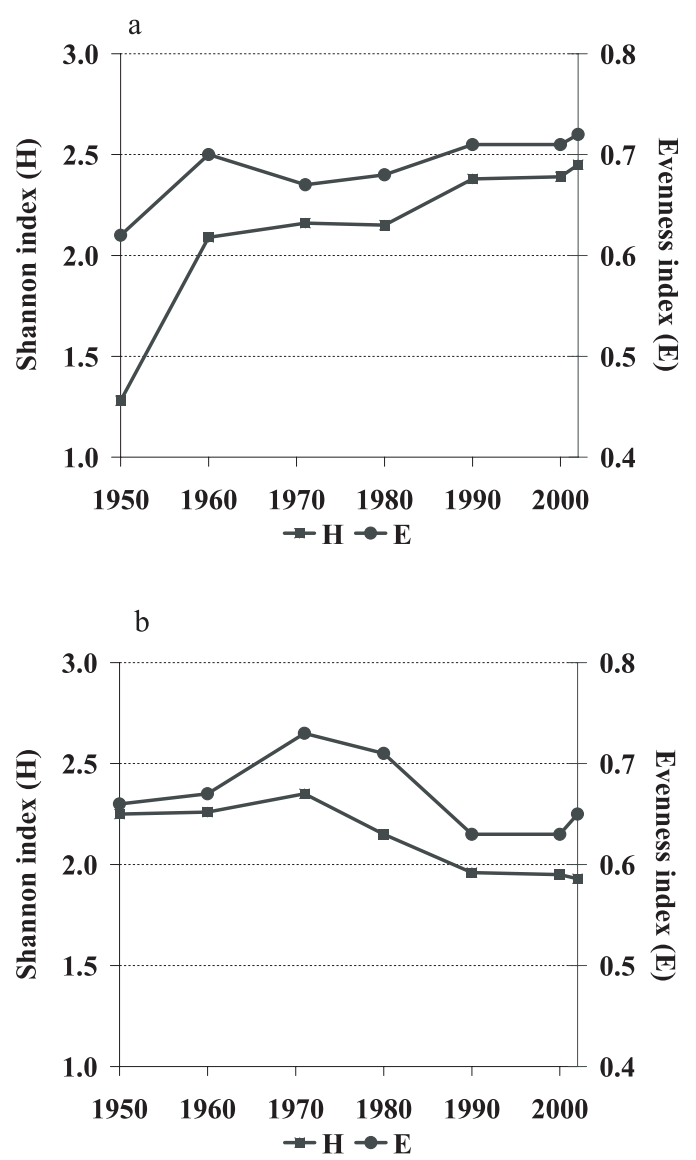

Figure 2. Shannon and evenness indices for vegetables (a) and arable crops (b) in Flanders between 1950 and 2002.

\subsection{Discussion: CP versus DNA analysis}

Although computation of $\mathrm{CP}$ has a relatively low absolute precision, calculating averages and patterns may be useful for describing relative diversity in different regions or time periods (Cox et al., 1986; Murphy et al., 1986; Soleimani et al., 2002). Errors are mainly caused by incorrect assumptions (Witcombe, 1999). The pedigree information of some cultivars may be incorrect or incomplete. Also, the assumption is made that a cultivar derived from a cross between two parents will inherit half of its genetic material from each parent (Souza and Sorrells, 1989; Tinker et al., 1993). However, this is only fully true when the variety is a direct product of the cross between two parents, e.g. in single hybrids. Effects caused by mutation or selection are not taken into account. 
Table II. Shannon $(H)$ and evenness $(E)$ indices, and percentage of pairs within a specific coefficient of parentage $(\mathrm{CP})$ class for maize, potato and winter wheat in 1980 and in 2002.

\begin{tabular}{|c|c|c|c|c|c|c|}
\hline & & & & & & \\
\hline & 1980 & 2002 & 1980 & 2002 & 1980 & 2002 \\
\hline$H$ & $-*$ & 4.29 & 0.63 & 2.00 & 2.17 & 3.25 \\
\hline E & $-*$ & 0.76 & 0.23 & 0.57 & 0.65 & 0.86 \\
\hline percentage of pairs $(\%) \mathrm{w}$ & & & & & & \\
\hline $\mathrm{CP} \geq 0.125$ & 1.8 & 7.5 & 7.3 & 3.7 & 6.9 & 6.0 \\
\hline $0.125>\mathrm{CP} \geq 0.0625$ & 12.7 & 8.5 & 1.8 & 5.5 & 7.6 & 1.3 \\
\hline $0.0625>\mathrm{CP} \geq 0.03125$ & 1.8 & 1.6 & 10.9 & 20.5 & 5.1 & 1.7 \\
\hline $0.03125>\mathrm{CP}>0$ & 0 & 0 & 56.4 & 66.9 & 17.4 & 0.5 \\
\hline $\mathrm{CP}=0$ & 83.7 & 82.5 & 23.6 & 3.4 & 63.0 & 90.5 \\
\hline
\end{tabular}

* no data available.

Recently, evaluation of genetic diversity has moved to the use of molecular markers, which are indicators of diversity at DNA level (Cox and Wood, 1999). Compared with pedigree analysis, DNA analysis may have a higher absolute precision for estimating genetic relatedness between varieties, but this precision is strongly dependent on the type and the number of markers that are used, their genome coverage and the crop studied (Messmer et al., 1993; Soleimani et al., 2002; Sun et al., 2003). Moreover, two cultivars may have the same allele of a particular marker simply by chance (i.e. they are identical "by state"), and not because they have inherited their alleles from a recent common parent (i.e. they are identical "by descent"). When a large enough array of markers is used, one can conclude that the genetic distance between two cultivars is indicated by the number of markers for which they carry contrasting alleles (Cox and Wood, 1999; Sun et al., 2003).

Correlation between relatedness measured either by $\mathrm{CP}$ or by molecular markers is often low (Schut et al., 1997; Sun et al., 2003); incongruities are the result of the inaccuracies of both methods. In this study we preferred pedigree data over DNA analysis, because calculation of $\mathrm{CP}$ is a quick, inexpensive and repeatable method that can essentially be applied by any person with basic knowledge of genetics.

\section{CONCLUSION}

In the literature, the number of crops or varieties is often used as the sole indicator for genetic diversity between and within crops. Our study has shown that this indicator is not sufficient to assess true genetic diversity. Therefore, we estimated crop diversity in Flanders by the Shannon and evenness indices. Although the number of crops has increased since 1950, the overall crop diversity did not increase; we rather observed a decreasing trend, caused by the increasing dominance of a limited number of arable crops. Genetic diversity within three crops was assessed by the Shannon and evenness indices and the relatedness between varieties. Considering the period 1980-2002, the indicators showed a decrease in diversity between maize varieties, and an increase in diversity within potato and winter wheat.
From this study, we are not able to make a sound conclusion on the true state of genetic diversity of crops in Flanders, since no reference base on genetic diversity exists (how much diversity is actually needed?). However, we did develop an instrument that can be used to describe the evolution in time of the genetic diversity of crops within a specific region.

Considering its importance in sustainable agriculture and the fact that there has been a decrease in genetic diversity in Flanders during the last few decades, the Flemish government should take measures to at least maintain the present genetic crop diversity. Moreover, genetic diversity of crops should be monitored now and in the future and it should be taken into account when developing new agricultural production systems.

\section{REFERENCES}

Bellamy A., Vedel F., Bannerot H. (1996) Varietal identification in Cichorium intybus L. and determination of genetic purity of F1 hybrid seed samples, based on RAPD markers, Plant Breeding 115, $128-132$.

Bertin P., Grégoire D., Massart S., de Froidmont D. (2001) Genetic diversity among European cultivated spelt revealed by microsatellites, Theor. Appl. Genet. 102, 148-156.

Christiansen M.J., Andersen S.B., Ortiz R. (2002) Diversity changes in an intensively bred wheat germplasm during the 20th century, Mol. Breeding 9, 1-11.

Clunies-Ross T., Mangolds (1995) Manure and mixtures. The importance of crop diversity on British farms, Ecologist 25, 181-187.

Collins W.W., Hawtin G.C. (1999) Conserving and Using Crop Plant Biodiversity in Agroecosystems, in: Collins W.W., Qualset C.O. (Eds.), Biodiversity in Agroecosystems, CRC Press, Boca Raton, pp. 267-282.

Cox T.S., Murphy J.P., Rodgers D.M. (1986) Changes in genetic diversity in the red winter wheat regions of the United States, Proc. Natl Acad. Sci. (USA) 83, 5583-5586.

Cox T.S., Wood D. (1999) The nature and role of crop biodiversity, in: Wood D., Lenné J.M. (Eds.), Agrobiodiversity: Characterisation, Utilisation and Management, CAB International, Wallingford, pp. 35-57.

Delbaere B. (2003) An Inventory of Biodiversity Indicators in Europe, 2002. Technical report No. 92, European Centre for Nature Conservation, Copenhagen. 
Desplanque B., Boudry P., Broomberg K., Saumitou-Laprade P., Cuguen J., Van Dijk H. (1999) Genetic diversity and gene flow between wild, cultivated and weedy forms of Beta vulgaris L. (Chenopodiaceae), assessed by RFLP and microsatellite markers, Theor. Appl. Genet. 98, 1194-1201.

Donini P., Law J.R., Koebner R.M.D., Reeves J.C., Cooke R.J. (2000) Temporal trends in the diversity of UK wheat, Theor. Appl. Genet. 100, 912-917.

Dotlacil L., Stehno Z. Michalova A., Faberova I. (2001) Plant genetic resources and agri-biodiversity in the Czech Republic, Meeting document of the OECD expert meeting on agri-biodiversity indicators, 5-8 November 2001, Zürich.

Falconer D.S. (1981) Introduction to Quantitative Genetics, 2nd ed., Longman inc., New York.

FAO, Global Plan of Action for the Conservation and Sustainable Utilization of Plant Genetic Resources for Food and Agriculture and the Leipzig Declaration, Adopted by the International Technical Conference on Plant Genetic Resources, 17-23 June 1996, Leipzig, Germany.

Finckh M.R., Gacek E.S. Goyeau H., Lannou C., Merz U., Mundt C.C., Munk L., Nadziak J., Newton A.C., de Vallavieille-Pope C., Wolfe M.S. (2000) Cereal variety and species mixtures in practice, with emphasis on disease resistance, Agronomie 20, 813-837.

Manifesto M.M., Schlatter A.R., Hopp H.E., Suárez E.Y., Dubcovsky J. (2001) Quantitative evaluation of genetic diversity in wheat germplasm using molecular markers, Crop Sci. 41, 682-690.

Marshall E.J.P., Brown V.K., Boatman N.D., Lutmans P.J.W., Squire G.R., Ward L.K. (2003) The role of weeds in supporting biological diversity within crop fields, Weed Res. 43, 77-89.

Messmer M.M., Melchinger A.E., Herrmann R.G., Boppenmaier J. (1993) Relationship among early European maize inbreds. II. Comparison of pedigree and RFLP data, Crop Sci. 33, 944-950.

Murphy J.P., Cox T.S., Rodgers D.M. (1986) Cluster analysis of red winter wheat cultivars based on coefficients of parentage, Crop Sci. 26 , 672-676.

NERI (1995) Nature indicators survey, Report to Topic Centre Paris, Ministry of the Environment and Energy \& National Environmental Research Institute, Denmark.

NIS (1950-2002) Annual agricultural statistics, National Institute of Statistics, Belgium.

OECD (2001) Environmental Indicators for Agriculture. Methods and Results. Vol. 3, Organisation for economic co-operation and development, Paris.
Pielou E.C. (1966) The measurement of diversity in different types of biological collections, J. Theor. Biol. 13, 131-144.

Reeves J.C., Law J.R., Donini P., Koebner R.M.D., Cooke R.J. (1999) Changes over time in the genetic diversity of UK cereal crops, Proceedings of the Technical Meeting on the methodology of the FAO World Information and Early Warning System on Plant Genetic Resources, 21-23 June 1999, Prague.

Schut J.W., Qi X., Stam P. (1997) Association between relationship measures based on AFLP markers, pedigree data and morphological traits in barley, Theor. Appl. Genet. 95, 1161-1168.

Shannon C.E., Weaver W. (1949) The mathematical theory of communication, The University of Illinois Press, Urbana.

Soleimani V.D., Baum B.R., Johnson D.A. (2002) AFLP and pedigreebased genetic diversity estimates in modern cultivars of durum wheat [Triticum turgidum L. subsp. durum (Desf.) Husn.], Theor. Appl. Genet. 104, 350-357.

Souza E., Sorrells M.E. (1989) Pedigree analysis of North American oat cultivars released from 1951 to 1985, Crop Sci. 29, 595-601.

Sun G., Wang-Pruski G., Mayich M., Jong H. (2003) RAPD and pedigreebased genetic diversity estimates in cultivated diploid potato hybrids, Theor. Appl. Genet. 107, 110-115.

Tinker N.A., Fortin M.G., Mather D.E. (1993) Random amplified polymorphic DNA and pedigree relationships in spring barley, Theor. Appl. Genet. 85, 976-984.

Tripp R., van der Heide W. (1996) The erosion of crop genetic diversity: challenges, strategies and uncertainties, Natural Resources Perspectives, 7 March 1996, Accessed on http://www.odi.org.uk/nrp/ 7.html.

Van Stallen N., Noten V., Demeulemeester M., De Proft M. (2000) Identification of commercial chicory cultivars for hydroponic forcing and their phenetic relationships revealed by random amplified polymorphic DNAs and amplified fragment length polymorphisms, Plant Breeding 119, 265-270.

Vellvé R. (1993) The decline of diversity in European agriculture, Ecologist 23, 64-69.

Wascher D.W. (2000) (Ed.) Agri-environmental indicators for sustainable agriculture in Europe, European Centre for Nature Conservation, Tilburg.

Witcombe J.R. (1999) Does plant breeding lead to a loss of genetic diversity? in: Wood D., Lenné J.M. (Eds.), Agrobiodiversity: Characterisation, Utilisation and Management, CAB International, Wallingford, pp. 245-272.

To access this journal online: www.edpsciences.org 